\title{
Generation of monoclonal antibody against protein phosphatase 5
}

\author{
O. M. Malanchuk ${ }^{1}$, G. V. Ovcharenko ${ }^{1}$, I. O. Tykhonkova ${ }^{1}$, O. S. Khoma ${ }^{2}$, \\ U. A. Chorna ${ }^{2}$, M. Yu. Rybak ${ }^{2}$, S. S. Palchevskyy ${ }^{1}$ \\ ${ }^{1}$ State Key Laboratory on Molecular and Cellular Biology \\ Institute of Molecular Biology and Genetics, NAS of Ukraine \\ 150, Akademika Zabolotnogo Str., Kyiv, Ukraine, 03680 \\ ${ }^{2}$ ESC «Institute of Biology» National Taras Shevchenko University of Kyiv \\ 64/13, Volodymyrska Str., Kyiv, Ukraine, 01601 \\ o.m.malanchuk@imbg.org.ua
}

\begin{abstract}
Aim. Serine/threonine protein phosphatase 5 (PP5) is a unique member of serine/threonine phosphatase family, comprises a regulatory tetratricopeptide repeat (TPR) domain and regulates many cell signaling pathways. Here, we describe the development of a PP5 specific monoclonal antibody $(\mathrm{mAb})$ and characterize its suitability for Western blotting and immunoprecipitation. Methods. Hybridoma technology has been used for monoclonal antibody generation. Immunization was carried out with recombinant mouse PP5 expressed in Escherichia coli as a GST-tagged fusion protein. Results. mAb against PP5 has been generated. Conclusions. Generated mAb specifically recognizes recombinant and endogenous mouse and rat PP5 and is suitable for Western blotting and immunoprecipitation. This $m A b$ will be useful tool for investigations of PP5 physiological role.
\end{abstract}

Keywords: protein phosphatase 5, hybridoma technique, monoclonal antibody.

Introduction. Serine/threonine protein phosphatase 5 (PP5) is a member of the PPP family of serine/threonine phosphatases, which includes PP1, PP2A, PP2B, PP2C, PP4, PP6 and PP7 [1]. PP5 possesses four N-terminal tetratricopeptide repeat (TPR) domains [2], which are implicated in protein-protein interactions [38]. The catalytic activity of PP5 was reported to be inhibited in vitro by an okadaic acid/cantharidin/microcystin and activated by arachidonic acid [2,9]. Although, PP5 is highly conserved among species the biological and pathological role of PP5 is not clear yet. It has been shown that PP5 is ubiquitously expressed in normal tissues, and high PP5 protein expression level has been observed in different types of human cancer [10-15]. PP5 exists in cell in different multiprotein complexes and has been reported to be involved in the regulation of various biological processes such as glucocorticoid

(C) Institute of Molecular Biology and Genetics, NAS of Ukraine, 2013 receptor activity [16-18], apoptosis [19-21], cell response to UV light or ionizing radiation [22, 23], genomic stress response [19-21, 24-26]; additionally, PP5 appears to play an important role in balancing the cellular responses to the transforming growth factor- $\beta$ (TGF- $\beta$ ) signal [27].

Recently we have identified PP5 as a new binding partner for a TSC2, a component of tuberous sclerosis complex TSC1/2 [28-30]. TSC1/2 complex serves as a point of integration between growth-stimulatory and growth-suppressive signaling upstream of mTOR in $\mathrm{PI} 3 \mathrm{~K} / \mathrm{Akt} / \mathrm{mTOR}$ signaling pathway. The last one is implicated in signal transduction from mitogenic growth factors, nutrients, cellular energy levels and stress conditions to stimulate protein synthesis and cell growth $[31,32]$. So far, very little is known about the molecular mechanisms of TSC2 dephosphorylation. Therefore, we hypothesized that the inter action with PP5 may control the phosphorylation status of TSC2. 
To analyze the specificity of interactions between TSC2 and PP5 we developed monoclonal antibody $(\mathrm{mAb})$, which recognizes PP5. Recombinant GSTtagged PP5 protein (GST-PP5) was used for mice immunization and hybridoma screening procedure. Here, we report that developed $\mathrm{mAb}$ specifically recognizes recombinant and endogenous PP5 in Western blotting and immunoprecipitation assay. This mAb could be a useful tool in study of PP5-mediated signal transduction pathways.

Materials and methods. Purification of GST-PP5 fusion protein. The bacterial expression system has been used for production of mouse full length GSTPP5 fusion protein. Generated plasmid pET42a/PP5 was transformed into Escherichia coli BL21 (lysE) and the expression of GST-PP5 fused protein was induced with $1 \mathrm{mM}$ isopropyl- $\beta-\mathrm{D}(2)$-thiogalactopyranoside (IPTG) for $3 \mathrm{~h}$ at $28{ }^{\circ} \mathrm{C}$. Affinity purification of GSTPP5 was carried out under native conditions using Glutathione-Sepharose («Amersham», UK) as recommended by manufactures. The quality of the purified recombinant protein was tested by sodium dodecyl sulfate-polyacrylamide gel electrophoresis (SDS-PAGE).

Production of hybridomas. Briefly, generation of $\mathrm{mAb}$ has been performed as described earlier [34]. Female BALB/c mice (6-8 weeks old) were immunized with $20 \mu \mathrm{g}$ of recombinant GST-PP5 fusion protein in complete Freund's adjuvant by intraperitoneal injections (i. p.) every two weeks. When the titer of anti-PP5 antibody in the serum of immunized mouse reached $10^{-5}$, the hybridomas production was performed according to a standard protocol [33]. Immunized mice were boosted with $20 \mu \mathrm{g}$ of antigen in phosphate-buffered saline (PBS) by i. p. injection. Three days later, spleenocytes from immunized mouse and SP2/0 myeloma cells were fused in the presence of PEG (MW 2000, «Merck», Germany). SP2/0 myeloma cells were cultured in RPMI 1640 medium containing $20 \%$ fetal calf serum (FCS). Primary screening of hybridoma supernatants was performed 7 days later using ELISA. Isolated positive clones were subcloned by limiting dilution method [33].

ELISA assay. Polystyrene 96-well plates were loaded with GST-PP5 in the concentration $0.3 \mu \mathrm{g} /$ well for $2 \mathrm{~h}$ at $37^{\circ} \mathrm{C}$. The plates were washed three times with PBS containing $0.1 \%$ Tween-20 («Sigma», USA). For blocking of non-specific binding plates were incubated with $2 \%$ bovine serum albumin (BSA) in PBS (pH 7.4) overnight at $4{ }^{\circ} \mathrm{C}(200 \mu \mathrm{l} / \mathrm{well})$. Subsequently, the plates were loaded with $100 \mu \mathrm{l} /$ well aliquots of hybri doma supernatant and incubated for $1 \mathrm{~h}$ at $37^{\circ} \mathrm{C}$, serum from immunized mouse was used as positive control. After three times washing, $100 \mu 1$ of horseradish peroxidase (HRP)-conjugated goat anti-mouse IgG antibodies (1:5000 v/v, «Promega», USA) were added to each well following the incubation at $37^{\circ} \mathrm{C}$ for $1 \mathrm{~h}$. Plates were washed three times and substrate solution $\left(0.02 \% \mathrm{H}_{2} \mathrm{O}_{2}, 0.5 \mathrm{mg} / \mathrm{ml} \mathrm{2.2'-azino-bis(3-ethylbenzo-}\right.$ thiazoline-6-sulfonic acid) sodium salt («Sigma») in $0.1 \mathrm{M}$ citrate-phosphate buffer ( $\mathrm{pH}$ 5.8)) was added to each well. After 15 -min incubation at $37^{\circ} \mathrm{C}$, the absorbance of the each well was determined at $490 \mathrm{~nm}$ in an ELISA reader.

Hybridoma selection in Western blot analysis. Bacterially expressed GST-PP5 recombinant protein was boiled in sample buffer, resolved by a $10 \%$ SDS-PAGE and electrotransferred to Immobilon-P membrane («Millipore», USA). The membrane was divided into strips, blocked by $0.5 \%$ gelatin in PBS for $1 \mathrm{~h}$ at room temperature (RT) followed by a single wash with PBS containing $0.1 \%$ Tween-20. Strips were incubated with either PBS, post-immune serum (1:1000), hybridoma supernatants from clones, or cell culture media alone for $4 \mathrm{~h}$ at RT. After three times washing, a HRPconjugated goat anti-mouse $\operatorname{lgG}$ («Promega») was added to the strips and incubated for $1 \mathrm{~h}$ at RT. Strips were washed three times, and developed by ECL Western blotting reagent («Amersham», Sweden).

Purification of $m A b$. For monoclonal antibody ascites fluid production $\mathrm{BALB} / \mathrm{c}$ mice were injected with $0.5 \mathrm{ml}$ of pristane and 7-10 days later inoculated with $5 \cdot 10^{6}$ of hybridoma cells [34]. The ascitic fluid was collected after 7-10 days. The fraction of immunoglobulins was precipitated from ascitic fluid with $50 \%$ ammonium sulphate, dialyzed overnight against $\mathrm{PBS}, \mathrm{pH}$ 7.4 and purified by affinity chromatography using Protein A-Sepharose CL-4B («Amersham», Sweden). The IgG fractions were pulled together and dialyzed against PBS. The aliquots of purified antibodies were stored at $-70{ }^{\circ} \mathrm{C}$.

Production of polyclonal serum. Polyclonal serum has been collected from an immunized mouse by tail 
bleed before the hybridomas production was performed. Collected blood was incubated at $37^{\circ} \mathrm{C}$ for $1 \mathrm{~h}$ then transferred to $4{ }^{\circ} \mathrm{C}$ for $2 \mathrm{~h}$, and after that spinned down at $1500 \mathrm{rpm}$ for $15 \mathrm{~min}$ at $4{ }^{\circ} \mathrm{C}$. Serum was removed from cell pellet avoiding the packed one, diluted with equal volume of glycerol and stored at $-20^{\circ} \mathrm{C}$.

Cell lines. $\mathrm{TSC}_{2}^{+/+} \mathrm{p} 53^{--}$and $\mathrm{TSC} 2^{--} \mathrm{p} 53^{--}$MEFs (mouse embryonic fibroblast), HEK293 (human embryonal kidney), MCF-7 (human breast adenocarcinoma), $\mathrm{CHO}$ (Chinese hamster ovary cells) and HeLa (human cervical cancer cells) were grown in DMEM medium supplemented with $10 \%(\mathrm{v} / \mathrm{v}) \mathrm{FCS}$ and $2 \mathrm{mM}$ L-glutamine. Sp2/0 (murine myeloma) cells were cultivated in RPMI-1640 medium supplemented with $10 \%$ (v/v) FCS and $2 \mathrm{mM}$ L-glutamine.

Immunoblotting of cell lysates and organ extracts. $\mathrm{TSC}^{+/ /} \mathrm{p} 53^{-/-}$MEFs, TSC2 $2^{--} \mathrm{p} 53^{---}$MEFs and HEK293 cell lines and both mouse and rat kidney, liver, spleen, lung and brain extracts were lysed with lysis buffer (50 mM Tris-HCI, pH 7.5, $150 \mathrm{mM} \mathrm{NaCl}, 1 \%$ NP40, $50 \mathrm{mM} \mathrm{NaF}, 2 \mathrm{mM}$ EDTA, $\left.10 \mathrm{mM} \mathrm{Na}_{4} \mathrm{P}_{2} \mathrm{O}_{7}\right)$ containing the protease inhibitors cocktail ( $«$ Roche Molecular Diagnostics», France) and spinned down at $10000 \mathrm{rpm}$ for $10 \mathrm{~min}$. Protein concentration in supernatant was estimated by BCA assay («Pierce», USA), and equal amounts of protein $(50 \mu \mathrm{g})$ were resolved in SDSPAGE. Gels were transferred to polyvinylidene difluoride (PVDF) membrane («Millipore»). The membrane was blocked with $0.5 \%$ gelatine in PBS containing $0.05 \%$ Tween-20 (PBST) for $1 \mathrm{~h}$ at RT and incubated overnight $(\mathrm{o} / \mathrm{n})$ with different dilutions of selected hybridoma supernatants at $4{ }^{\circ} \mathrm{C}$. After washing with PBST, membrane was stained with HRP-conjugated goat antimouse $\lg \mathrm{G}$ («Promega») during $1 \mathrm{~h}$ at RT. As a loading control, mouse anti-actin antibody was used («Sigma»). Western blot membranes were developed ECL Western blotting reagent («Amersham», Sweden).

Immunoprecipitation. Hybridoma supernatants from selected clones were incubated with $25 \mu 1$ of $50 \%$ suspension of Protein A-Sepharose CL-4B («Amersham», Sweden) for $2 \mathrm{~h}$ at $4{ }^{\circ} \mathrm{C}$. Then, beads were washed three times in lysis buffer above and the lysates $(500 \mu \mathrm{g}$ of protein) from cell lines $\mathrm{TSC}^{+/ /} \mathrm{p} 53^{-/-}$MEFs cells, HEK 293, HeLa, CHO, MCF7, rat brain extract were added. After incubation o/n at $4{ }^{\circ} \mathrm{C}$, beads were washed four times with $1 \mathrm{ml}$ of lysis buffer. Immune complexes we- re removed from beads by boiling in Laemmli sample buffer and separated by SDS-PAGE. Resolved proteins were visualized by Coomassie staining or transferred onto PVDF membrane for immunoblotting.

Results and discussion. Recent progress toward understanding the mechanism of control on cell growth indicates that the tuberous sclerosis complex TSC1/2 as tumor suppressor an upstream negative regulator of mTOR activity. However, the regulation of tumor suppression by TSC 1 and TSC 2 is not well understood. We were interested in the elucidation of molecular mechanisms, which regulated TSC1/2 function in cellular response to various extracellular stimuli. In the previous study, by the yeast two-hybrid screening we identified already known and novel binding partners for TSC1 and TSC 2 including Ser/Thr protein phosphatase 5 designated PP5 [28]. To analyze the specificity of interactions between TSC 2 and PP5 and to explore a potential effect of PP5 on TSC2 phosphorylation status we developed monoclonal antibody, which would specifically recognize PP5 in vivo.

Production and characterization of recombinant PP5 protein. We used the bacterial expression system to produce recombinant PP5 for mouse immunization and hybridoma clone screening. The full length of mouse PP5 was amplified by PCR and cloned into pET42a vector in frame with the GST-tag sequence to facilitate purification of recombinant protein. GST-PP5 was highly expressed upon IPTG induction and shown to be soluble under native conditions (Fig. 1, $A$ ). For GST-PP5 fusion protein purification Glutathione-Sepharose affinity chromatography was used (Fig. 1, B).

Hybridoma production and isolation of positive clones. BALB/c mice were immunized with $20 \mu \mathrm{g}$ of purified GST-PP5 fusion protein in complete Freund's adjuvant every two weeks. Animals developed strong immune response to the antigen, and the titer of specific antibody reached $10^{-5}$ in all immune sera after the third immunization. Immune spleen cells were fused with the myeloma cells Sp2/0 using PEG. After fusion cells were incubated in RPMI medium containing antibiotics, $20 \%$ fetal bovine serum, and hypoxanthine/ aminopterin/thymidine (HAT) as a selective agent. Ten days later the first ELISA screening was carried out using GST-PP5 fusion protein to coat ELISA plate. We selected 14 positive hybridoma clones in the first round 

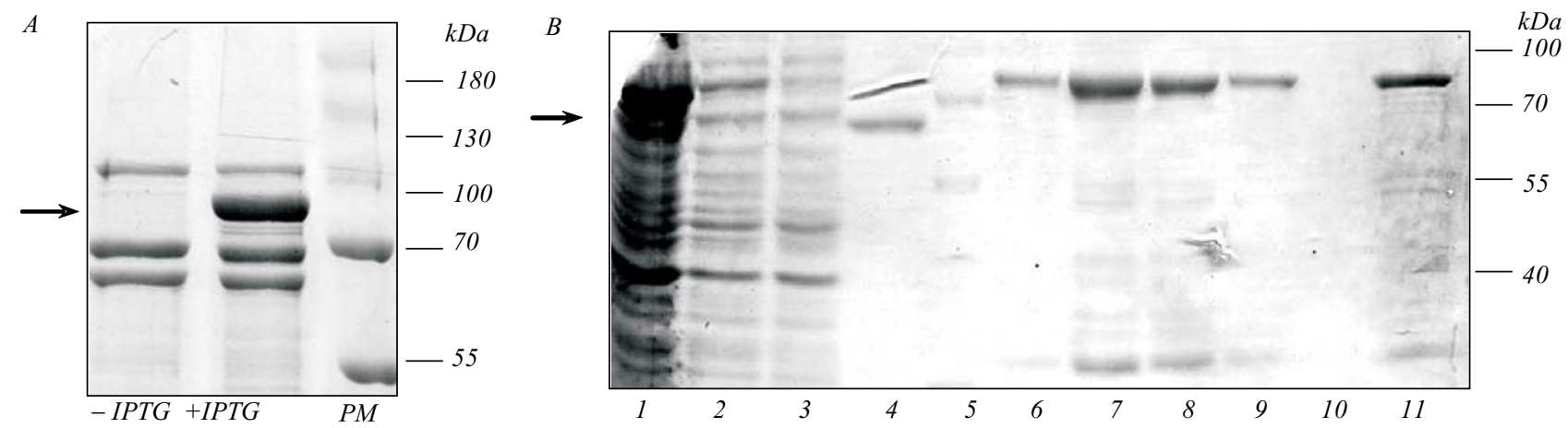

Fig. 1. Analysis of expression and affinity purification of recombinant GST-PP5 by SDS-PAGE: A - expression of GST-PP5 in BL21 pLysE cells was induced by IPTG (harvested cells were lysed in lysis buffer and centrifuged at $13000 \mathrm{rpm}$ for 20 min; total cell lysates and the supernatants from the IPTG induced and non-induced cells were separated by SDS-PAGE and Coomassie stained); $B$ - affinity purification of GST-PP5 protein on GST-sepharose under native conditions (the GST-PP5 expressing cells were incubated with the GST-sepharose as described in Material and methods; after extensive washing, bound proteins were eluted in buffer containing $250 \mathrm{mM}$ imidazole; obtained fractions were resolved by SDSPAGE and Coomassie stained); lane 1 - total lysate; lane 2 - lysate before GST-seph. binding; lane 3 - lysate after GST-seph. binding; lane $4-$ BSA; lane 5 - Protein Marker; lane 6-9-elution 1-4, respectively; lane 10 - blank; lane 11 - GST-sepharose after elution. The position of recombinant GST-PP5 is indicated by arrows

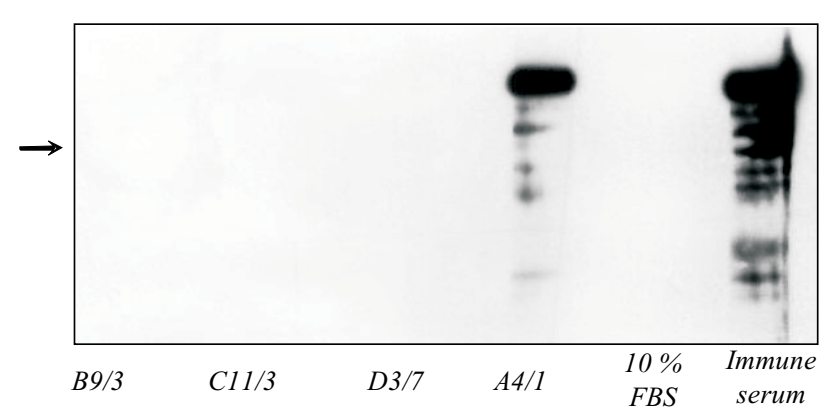

Fig. 2. Western-blot analysis of hybridoma supernatants from different clones with recombinant GST-PP5. Recombinant GST-PP5 was separated in numerous lanes by SDS-PAGE and transferred to PVDF membrane. The strips of membranes, corresponding to one lane were immunoblotted with hybridoma media from PP5 positive supernatants. AntiPP5 polyclonal serum and $10 \%$ fetal bovine serum (FBS) were used as positive and negative control, respectively. The position of GST-PP5 protein is indicated by arrows

of screening. For selected clones a second ELISA screening was performed three days later and confirmed the GST-PP5 specificity for 4 clones. Selected clones were further subcloned twice using limiting dilution method.

Testing the specificity of selected clones in Western blotting. Supernatants from four positive clones were then tested by Western blotting using GST-PP5 protein. RPMI medium with $10 \%$ FBS was used as a negative control. The serum collected from GST-PP5 immunized mouse was used as positive control. The obtained results clearly indicate that only one $\mathrm{mAB}$, which designated as A4/1, recognizes a protein at the level corresponding to GST-PP5 (Fig. 2).

Produced antibodies recognize endogenous PP5. To determine whether the selected A4/1 mAb can recognize endogenous PP5, we tested their specificity in Western blotting and immunoprecipitation assay using cell lysates from different cell lines and organ extracts from mouse and rat. For these purposes $50 \mu \mathrm{g}$ of cell lysates from $\mathrm{TSC}_{2}{ }^{+/} \mathrm{p} 53^{-/-}$MEFs, TSC2 $2^{-/} \mathrm{p} 53^{-/}$MEFs, HEK 293, HeLa cell lines and organ extracts from mouse and rat brain, kidney, liver, spleen, and lung were analyzed in Western blot with $\mathrm{A} 4 / 1 \mathrm{mAb}$. We found that $\mathrm{mAb}$ A4/1 recognizes a protein of approximately $58 \mathrm{kDa}$ in $\mathrm{TSC}_{2}^{+/+} \mathrm{p} 53^{-/-}$MEFs and TSC2 $2^{---} \mathrm{p} 53^{-/-}$MEFs but not in HEK293 cell lines (Fig. 3, A). Moreover, we also found that $\mathrm{A} 4 / 1 \mathrm{mAb}$ recognizes specifically endogenous PP5 in immunoblot analysis of mouse and rat protein extracts from brain, kidney, liver, spleen and lung (Fig. 3, B).

Then, we tested the ability of selected mAb to immunoprecipitate endogenouse PP5. In this assay, we used protein extracts from rat brain, $\mathrm{TSC}^{+/+} \mathrm{p} 53^{-/-}$ MEFs cells, HEK 293, HeLa, CHO, MCF7 cell lines and IgGs from selected clone A4/1. Immune complexes were resolved by SDS-PAGE and immunoblotted with A4/1 mAb. The Protein A-Sepharose pre-incubated with lysate from $\mathrm{TSC}^{+/ /} \mathrm{p} 53^{-/-}$MEFs alone served as a negative control. 

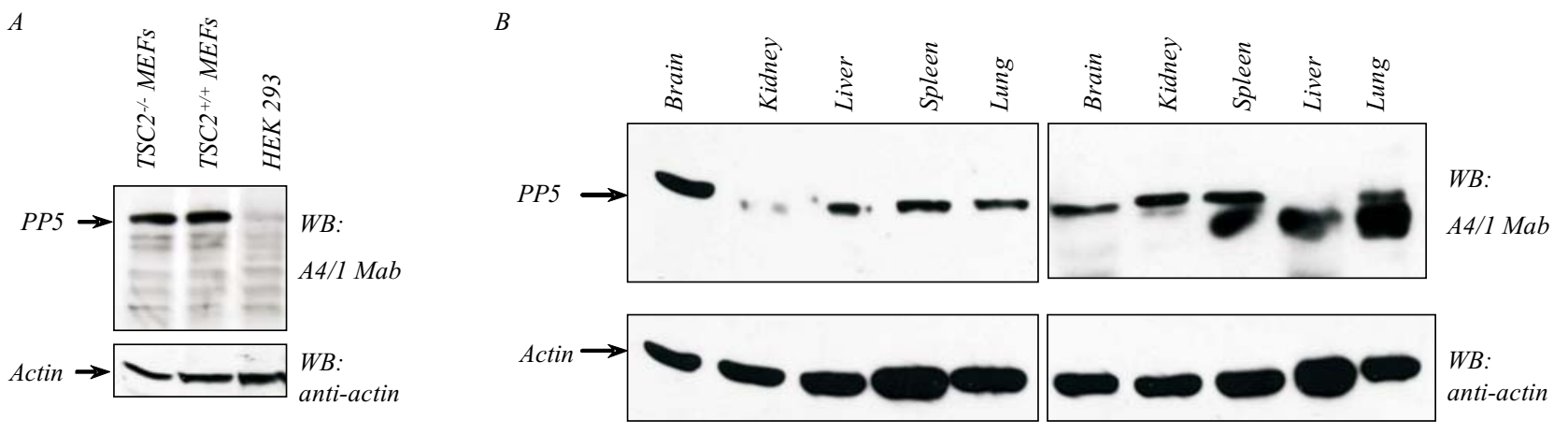

Fig. 3. Western-blot analysis of monoclonal antibody A4/1 using cell lines and tissues: $A$ - endogenous PP5 is specifically recognized by A4/1 $\mathrm{mAb}$ in Western blotting of TSC2 $2^{+/ \mid} \mathrm{p} 53^{--\alpha}$ MEFs and $\mathrm{TSC}^{-/} \mathrm{p} 53^{-/-}$MEFs cell lines (total cell lysates $(50 \mu \mathrm{g})$ were separated by SDS-PAGE and immunoblotted with A4/1 mAb); $B$ - endogenous PP5 is specifically recognized by A4/1 mAb in Western blotting of rat (right) and mouse (left) extracts of organs (total organ extracts $(50 \mu \mathrm{g}$ ) were separated by SDS-PAGE and immunoblotted with A4/1 mAb)
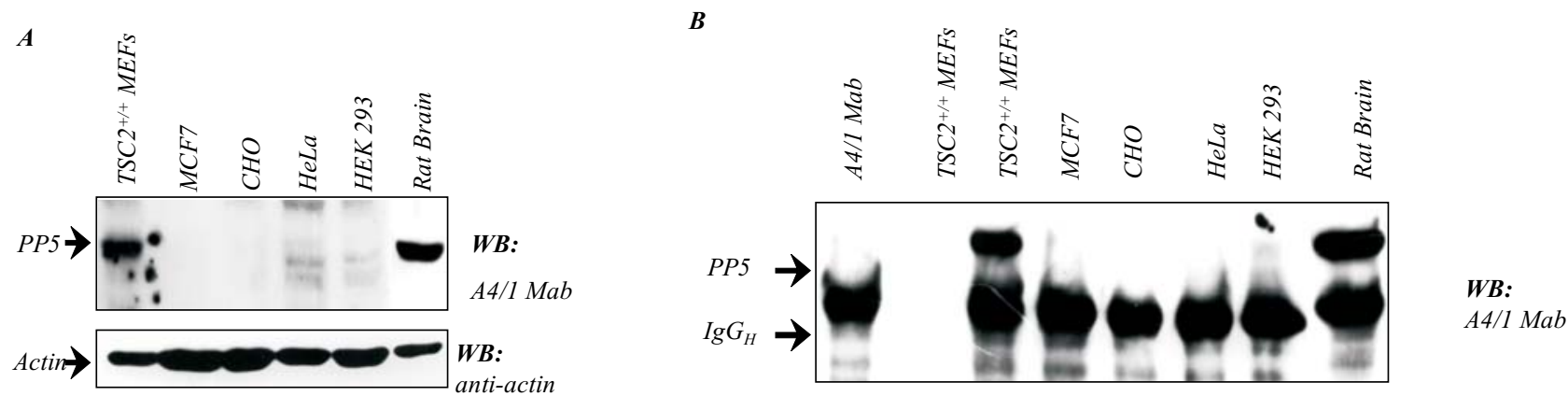

Fig. 4. Application of monoclonal antibody A4/1 in immunoprecipitation assay: $A$ - the pattern of expression of PP5 in supernatants (50 $\mu \mathrm{g})$ from $\mathrm{TSC}^{+/+} \mathrm{p}^{-1-}$ MEFs cells, HEK293, HeLa, CHO, MCF7, and extract of rat brain $(50 \mu \mathrm{g})$ were analysed in Western blotting; $B-$ cell lysates from $\mathrm{TSC}^{+/+} \mathrm{p}^{-/-}$MEFs cells, HEK293, HeLa, CHO, MCF7 and extract of rat brain $(500 \mu \mathrm{g})$ were incubated with Protein A-Sepharose containing IgGs from A4/1 mAb. After extensive washing of beads with cell lysis buffer, specifically associated proteins were resolved by SDS-PAGE and immunoblotted with A4/1 mAb. Lanes $A 4 / 1 \mathrm{Mab}$ and $T S C 2^{+/+} M E F S$ serves as positive and negative controles, respectively.

We found that selected $\mathrm{mAb}$ was able to immunoprecipitate specifically PP5 from TSC2 $2^{+/+} \mathrm{p} 53^{-/-}$MEFs and rat brain extract (Fig. 4). However, despite PP5 is highly conserved among species, generated $\mathrm{mAb}$ and polyclonal serum (data not shown) didn't recognize endogenous PP5 in human (HEK293, HeLa, MCF7) or hamster cells (CHO) neither under Western-blot analysis nor immunoprecipitation assay (Fig. 3, 4). One possible explanation is that antigen's epitope for mAb A4/1 may contain some non-homologous amino acids.

Taken together, this study describes the production of monoclonal antibody, which recognizes mouse and rat PP5. Generated $\mathrm{mAb}$ could be suitable for various immunoassays, including ELISA, Western blotting and immunoprecipitation. This $\mathrm{mAb}$ could be a useful tool in study of PP5-mediated signaling under different pathophysiological condition.
Acknowledgements. This work was particularly supported by state Fund for fundamental researches, Grant N F46/457-2011 and the President of Ukraine for young scientists, project N GP/F36/095 on «Investigation of molecular mechanisms of regulation of TSC2 tumor supressor activity».

\section{О. М. Маланчук, Г. В. Овчаренко, І. О. Тихонкова, О. С. Хома, У. А. Чорная, М. Ю. Рибак, С. С. Пальчевский}

Отримання моноклональних антитіл до протеїнфосфатази 5

\section{Резюме}

Мета. Серин-треонінова протеїнфосфатаза 5 (РР5) є унікальним членом родини серин-треонінових протеїнфосфатаз, оскільки містить регуляторні тетратрикопептидні повтори (TPR). PP5 бере активну участь у процесах сигнальної трансдукиії. Описано процедуру отримання моноклональних антитіл, специфічних до РР5, а також особливості їхнього використання у Вестерн-блот аналізі та імунопреципітації. Методи. Гібридомну технологію застосовано для отримання моноклональних анти- 
тіл. Імунізацію проводили рекомбінантним злитим білком GSTтаг, синтезованим у бактерійній системі. Результати. Одержано специфічні моноклональні антитіла проти РР5. Висновки. Моноклональні антитіла специифічно розпізнають рекомбінантну та ендогенну РР5 у Вестерн-блот анализі та імунопреципітаиії. Вони можуть стати необхідним інструментом при дослідженні фізіологічної ролі РР5.

Ключові слова: протеїнфосфатаза 5, гібридомна технологія, моноклональні антитіла.

О. Н. Маланчук, Г. В. Овчаренко, И. А. Тихонкова, А. С. Хома, У. А. Чорна, М. Ю. Рибак, С. С. Пальчевский

Получение моноклональных антител к протеинфосфатазе 5

Резюме

Цель. Серин-треониновая протеинфосфатаза 5 (РР5) является уникальным иленом семейства серин-треонинових протеинфосфатаз, поскольку содержит регуляторные тетратрикопептидные повторы (TPR). PP5 активно участвует в проиессах сигнальной трансдукции. Описаны процедура получения моноклональных антител, специфичных к РP5, а также особенности их использования в Вестерн-блот анализе и иммунопреципитации. Методы. Гибридомная технология применена для получения моноклональных антител. Иммунизаиию проводили рекомбинантным слитым белкомGST-таг, синтезированным в бактериальной системе. Результаты. Получены специфические моноклональные антитела против РР5. Выводы. Моноклональные антитела спещифично распознают рекомбинантную и эндогенную РP5 в Вестерн-блот анализе и иммунопрециичтации. Они могут стать необходимым инструментом при исследовании физиологической роли РP5.

Ключевые слова: протеинфосфатаза 5, гибридомная технология, моноклональные антитела.

\section{REFERENCES}

1. Russell L. C., Whitt S. R., Chen M. S., Chinkers M. Identification of conserved residues required for the binding of a tetratricopeptide repeat domain to heat shock protein 90 // J. Biol. Chem.1999.-274, N 29.-P. 20060-20063.

2. Chen M. X., McPartlin A. E., Brown L., Chen Y. H., Barker H. M., Cohen P. T. A novel human protein serine/threonine phosphatase, which possesses four tetratricopeptide repeat motifs and localizes to the nucleus // EMBO J.-1994.-13, N 18.P. 4278-4290.

3. Blatch G. L., Lassle M. The tetratricopeptide repeat: a structural motif mediating protein-protein interactions // Bioessays.-1999.21, N 11.-P. 932-939.

4. Chen M. S., Silverstein A. M., Pratt W. B., Chinkers M. The tetratricopeptide repeat domain of protein phosphatase 5 mediates binding to glucocorticoid receptor heterocomplexes and acts as a dominant negative mutant // J. Biol. Chem.-1996.-271, N 50.P. 32315-32320.

5. Morita K., Saitoh M., Tobiume K., Matsuura H., Enomoto S., Nishitoh $H$., Ichijo $H$. Negative feedback regulation of ASK1 by protein phosphatase 5 (PP5) in response to oxidative stress // EMBO J.-2001.-20, N 21.-P. 6028-6036.

6. von Kriegsheim A., Pitt A., Grindlay G. J., Kolch W., Dhillon A. $S$. Regulation of the Raf-MEK-ERK pathway by protein phosphatase 5 // Nat.Cell Biol.-2006.-8, N 9.-P. 1011-1016.

7. Chinkers $M$. Protein phosphatase 5 in signal transduction // Trends Endocrinol. Metab.-2001.-12, N 1.-P. 28-32.
8. Yong W., Bao S., Chen H., Li D., Sanchez E. R., Shou W. Mice lacking protein phosphatase 5 are defective in ataxia telangiectasia mutated (ATM)-mediated cell cycle arrest // J. Biol. Chem.2007.-282, N 20.-P. 14690-14694.

9. Chen M. X., Cohen P. T. Activation of protein phosphatase 5 by limited proteolysis or the binding of polyunsaturated fatty acids to the TPR domain // FEBS Lett.-1997.-400, N 1.-P. 136140.

10. Ghobrial I. M., McCormick D. J., Kaufmann S. H., Leontovich A. A., Loegering D. A., Dai N. T., Krajnik K. L., Stenson M. J., Melhem M. F., Novak A. J., Ansell S. M., Witzig T. E. Proteomic analysis of mantle-cell lymphoma by protein microarray // Blood.2005.-105, N 9.-P. 3722-3730.

11. Shirato H., Shima H., Nakagama H., Fukuda H., Watanabe Y., Ogawa K., Matsuda Y., Kikuchi K. Expression in hepatomas and chromosomal localization of rat protein phosphatase 5 gene // Int. J. Oncol.-2000.-17, N 5.-P. 909-912.

12. Golden T., Aragon I. V., Rutland B., Tucker J. A., Shevde L. A., Samant R. S., Zhou G., Amable L., Skarra D., Honkanen R. E. Elevated levels of Ser/Thr protein phosphatase 5 (PP5) in human breast cancer// Biochim. Biophys. Acta.-2008.-1782, N 4.P. 259-270.

13. Golden T., Aragon I. V., Zhou G., Cooper S. R., Dean N. M., Honkanen R. E. Constitutive over expression of serine/threonine protein phosphatase 5 (PP5) augments estrogen-dependent tumor growth in mice // Cancer Lett.-2004.-215, N 1.-P. 95-100.

14. Golden T., Swingle M., Honkanen R. E. The role of serine/threonine protein phosphatase type 5 (PP5) in the regulation of stressinduced signaling networks and cancer // Cancer Metastasis Rev.-2008.-27, N 2-P. 169-178.

15. Fukuda H., Tsuchiya N., Hara-Fujita K., Takagi S., Nagao M., Nakagama H. Induction of abnormal nuclear shapes in two distinct modes by overexpression of serine/threonine protein phosphatase 5 in Hela cells // J. Cell Biochem.-2007.-101, N 2.-P. 321-330.

16. Vaughan C. K., Mollapour M., Smith J. R., Truman A., Hu B., Good V. M., Panaretou B., Neckers L., Clarke P. A., Workman P., Piper P. W., Prodromou C., Pearl L. H. Hsp90-dependent activation of protein kinases is regulated by chaperone-targeted dephosphorylation of Cdc37 // Mol. Cell.-2008.-31, N 6.P. 886-895.

17. Shao J., Hartson S. D., Matts R. L. Evidence that protein phosphatase 5 functions to negatively modulate the maturation of the Hsp90-dependent heme-regulated eIF2alpha kinase // Biochemistry.-2002.-41, N 21.-P. 6770-6779.

18. Skarra D. V., Goudreault M., Choi H., Mullin M., Nesvizhskii A. I., Gingras A. C., Honkanen R. E. Label-free quantitative proteomics and SAINT analysis enable interactome mapping for the human Ser/Thr protein phosphatase 5 // Proteomics.-2011.-11, N 8.-P. 1508-1516.

19. Mkaddem S. B., Werts C., Goujon J. M., Bens M., Pedruzzi E., Ogier-Denis E., Vandewalle A. Heat shock protein gp96 interacts with protein phosphatase 5 and controls toll-like receptor 2 (TLR2)-mediated activation of extracellular signal-regulated kinase (ERK) $1 / 2$ in post-hypoxic kidney cells // J. Biol. Chem.2009.-284, N 18.-P. 12541-12549.

20. Zhou G., Golden T., Aragon I. V., Honkanen R. E. Ser/Thr protein phosphatase 5 inactivates hypoxia-induced activation of an apoptosis signal-regulating kinase $1 / \mathrm{MKK}-4 / \mathrm{JNK}$ signaling cascade // J. Biol. Chem.-2004.-279, N 45.-P. 46595-46605.

21. Huang S., Shu L., Easton J., Harwood F. C., Germain G. S., Ichijo $H$., Houghton P. J. Inhibition of mammalian target of rapamycin activates apoptosis signal-regulating kinase 1 signaling by suppressing protein phosphatase 5 activity // J. Biol. Chem.-2004.279, N 35.-P. 36490-36496. 
22. Zhang J., Bao S., Furumai R., Kucera K. S., Ali A., Dean N. M., Wang $X$. F. Protein phosphatase 5 is required for ATR-mediated checkpoint activation // Mol. Cell Biol.-2005.-25, N 22.P. 9910-9919.

23. Ali A., Zhang J., Bao S., Liu I., Otterness D., Dean N. M., Abraham R. T., Wang X.F. Requirement of protein phosphatase 5 in DNA-damage-induced ATM activation // Genes Dev.-2004.18, N 3.-P. 249-254.

24. Wechsler T., Chen B. P., Harper R., Morotomi-Yano K., Huang B. C., Meek K., Cleaver J. E., Chen D. J., Wabl M. DNA-PKcs function regulated specifically by protein phosphatase 5 // Proc. Natl Acad. Sci. USA.-2004.-101, N 5.-P. 1247-1252.

25. Morita K., Saitoh M., Tobiume K., Matsuura H., Enomoto S., Nishitoh $H$., Ichijo $H$. Negative feedback regulation of ASK1 by protein phosphatase 5 (PP5) in response to oxidative stress // EMBO J.-2001.-20, N 21.-P. 6028-6036

26. Kutuzov M. A., Andreeva A. V., Voyno-Yasenetskaya T. A. Regulation of apoptosis signal-regulating kinase 1 (ASK1) by polyamine levels via protein phosphatase 5 // J. Biol. Chem.-2005.280, N 27.-P. 25388-25395.

27. Bruce D. L., Macartney T., Yong W., Shou W., Sapkota G. P. Protein phosphatase 5 modulates SMAD3 function in the transforming growth factor- $\beta$ pathway // Cell Signal.-2012.-24, N 11.P. 1999-2006.
28. Malanchuk O. M., Pozur V., Panasyuk G. G., Nemazanyy I. O., Filonenko V. V., Gout I. T., Palchevskyy S. S. Identification of novel binding partners for tuberous sclerosis complex 2 (TSC2) by yeast two-hybrid approach // Exp. Oncol.-2005.-27, N 3.P. 186-190.

29. Malanchuk O. M., Palchevskyy S. S., Pozur V. K., Gout I. T., Filonenko $V$. $V$. Interaction of serine/threonine protein phosphatase 5 with the protein products of tumour suppressor gene Tsc2 // Biopolym. Cell.-2007.-23 , N 4.-P. 318-323.

30. Malanchuk O. M., Palchevskyy S. S., Filonenko V. V. Dephosphorylation of tuberous sclerosis complex 2 by serine/threonine protein phosphatase 5 // Biopolym. Cell.-2008.-24, N 2.P. 176-179.

31. Gao X., Pan D. TSC1 and TSC2 tumor suppressors antagonize insulin signaling in cell growth // Genes Dev.-2001.-15, N 11.P. 1383-1392.

32. Kwiatkowski D. J. Tuberous sclerosis: from tubers to mTOR // Ann. Hum. Genet.-2003.-67, pt 1.-P. 87-96.

33. Harlow E., Lane D. Using antibodies: A laboratory manual.New York: Cold Spring Harbor Lab. press, 1998.-495 p.

34. Hurrell J. G. R. Monoclonal hybridoma antibodies: Techniques and application.-Boca Raton: CRC press, 1982.-231 p.

Received 17.12.12 